\title{
Mammaglobin Expression in Gynecologic Malignancies and Malignant Effusions Detected by Nested Reverse Transcriptase-Polymerase Chain Reaction
}

\author{
Kurt Grünewald, Margot Haun, Michael Fiegl, Martina Urbanek, \\ Elisabeth Müller-Holzner, Anita Massoner, Karin Riha, Albert Propst, \\ Christian Marth, and Günther Gastl
}

Department of Internal Medicine (KG, MH, MF, MU, AM, GG), Department of Obstetrics and Gynecology (EM-H, $K R, C M)$, and Department of Gastroenterology (AP), Division of Hematology and Oncology, University of Innsbruck, Innsbruck, Austria

SUMMARY: The detection of micrometastatic disease remains a challenge for the diagnosis and monitoring of malignant disease. RT-PCR for human mammaglobin (hMAM) was recently shown to provide a sensitive method for assessing circulating breast cancer cells in peripheral blood. This study was aimed at investigating hMAM expression in normal and malignant tissue from the female genital tract and the prostate as well as in malignant effusions derived from gynecologic malignancies. hMAM expression was analyzed with nested RT-PCR in 152 samples of normal $(n=73)$ and malignant epithelial tissues $(n=79)$ and in 33 specimens of various normal mesenchymal tissue types. We found hMAM expression was not restricted to the normal mammary gland and breast carcinoma but was also detectable in most specimens of benign and malignant epithelial tissue from the ovary $(97 \%$ versus $95 \%)$, uterus (both $100 \%)$, and cervix (91\% versus $90 \%)$. Notably, hMAM expression was also found in benign prostatic hyperplasia (45\%) and in prostate cancer (55\%). A much lower expression rate was found in various normal and benign mesenchymal tissues (12\%). In keeping with our previous data, hMAM expression was absent in all control samples ( $n$ $=124$ ) of peripheral blood and bone marrow from healthy volunteers and patients with hematologic malignancies. In pleural or peritoneal effusions $(n=42)$ from patients with carcinomas of the breast, endometrium, or ovary, hMAM positivity was noticed in the majority of cases $(74 \%)$, whereas only $52 \%$ of the specimens were cytologically positive for tumor cells. In conclusion, hMAM expression assessed by nested BT-PCR is a sensitive molecular marker for detecting micrometastatic tumor spread into pleural effusions and ascites from patients with breast cancer and various other gynecologic neoplasms. (Lab Invest 2002, 82:1147-1153).

$F$ arly occult dissemination of cancer cells is one of $E$ the main reasons for treatment failure and death despite optimal surgery and adjuvant therapies. Epithelial tissue-specific markers, which would allow the detection of micrometastatic disease in blood, tumordraining lymph nodes, and serous effusions at the time of primary tumor treatment, are sparse. Recently, human mammaglobin (hMAM) expression was found to be a sensitive molecular marker for the detection of micrometastatic breast cancer cells in peripheral blood, bone marrow, and tumor-draining lymph nodes (Grünewald et

\section{DOI: 10.1097/01.LAB.0000027840.16064.8A}

Received February 15, 2002.

This work was supported in part by the "Tiroler Verein zur Förderung der Krebsforschung" and by the "Verein zur Förderung von Forschung und Fortbildung in molekularer Genetik und Diagnostik internistischer Erkrankungen."

Address reprint requests to: Dr. Kurt Grünewald, Division of Hematology and Oncology, Department of Internal Medicine, Innsbruck University Hospital, Anichstraße 35, A-6020 Innsbruck, Austria. E-mail: kurt.gruenewald@uibk.ac.at al, 2000; Kataoka et al, 2000; Leygue et al, 1999; Manzotti et al, 2001; Marchetti et al, 2001; Min et al, 1998; Ooka et al, 2000, 2001; Zach et al, 1999). The clinical relevance of hMAM expression in blood samples from patients with breast carcinoma was demonstrated by a significant correlation between this molecular marker and nodal status, CA 15-3 levels in serum at the time of surgery, and the occurrence of distant metastases (Grünewald et al, 2000).

hMAM, a 10,000-molecular weight glycoprotein, belongs to the uteroglobin family and was first described in 1996 (Watson and Fleming, 1996). hMAM is encoded by a gene localized on chromosome 11q13 (Watson et al, 1998). So far, hMAM expression has been thought to be restricted to the normal mammary gland and mammary carcinoma. In fact, using the RT-PCR technique, Watson and Fleming found no hMAM expression in various benign tissue types or in neoplasias other than breast carcinoma (Watson and Fleming, 1996).

By screening effusions for micrometastatic disease in malignant effusions, we found that hMAM expression was not restricted to breast cancer effusions. 
Surprisingly it was also detected in other effusions derived from various gynecologic malignancies. Recently, Fleming and Watson have reported preliminary data on hMAM expression in carcinomas other than breast cancer (Fleming and Watson, 2000). These findings prompted us to screen a series of benign and malignant tissues as well as effusions for hMAM positivity by nested RT-PCR.

\section{Results}

\section{hMAM Expression in Nonbreast Epithelial and Mesenchymal Tissues}

Using two-step RT-PCR, we found hMAM gene expression in normal and malignant tissues outside the breast. In fact, this is the first report on frequent hMAM expression in a large series of malignant and nonmalignant tissues derived from the female genital tract including ovary, uterus, and cervix (Table 1). In addition, about half of the specimens of benign and malignant prostate tissue tested positive for hMAM. In contrast, hMAM expression in normal and benign tissues of mesenchymal origin was either absent or rather rare (Table 1).

Peripheral blood samples and leukapheresis products from healthy volunteers, as well as blood and bone marrow samples from patients with hematologic malignancies, were taken as controls. Indeed, hMAM expression was not detectable in these specimens. Based on our previous results, fresh-frozen tissues from invasive breast carcinomas were used as positive controls. These samples invariably showed hMAM expression by RT-PCR (Table 1). For data verification, the size-specific PCR products were sequenced. All of them revealed complete alignment with the published hMAM cDNA sequence. In addition hMAM amplification products were blotted and hybridized under stringent conditions with a specific cDNA probe for hMAM. All Southern blots showed the expected specific hybridization signal (data not shown).

\section{hMAM Expression in Cells from Malignant and Nonmalignant Ascitic and Pleural Effusions}

Freshly collected effusion samples were centrifuged, and RNA was extracted from pelleted effusion cells and processed for RT-PCR. hMAM expression was detected in all effusion samples $(n=16)$ from breast cancer patients, in $7(78 \%)$ of 9 effusions from endometrial carcinomas, in 6 (50\%) of 12 from ovarian carcinomas, and in effusions derived from two patients with granulosa cell tumor and carcinoma of the tube, respectively. Of note, hMAM expression was not seen in ascites from two patients suffering from malignant germ cell tumor of the ovary and carcinoma of the cervix. Results are summarized in Table 2. In effusions collected from patients without a history or evidence of a solid neoplasm, hMAM expression was detected in only $5(7 \%)$ of 70 samples (Table 3 ). Comparing the hMAM expression in this control group with hMAM expression in the presumably malignant, but cytologically negative effusions, there was a significant difference in favor of hMAM expression in malignant effusions ( $p<0.001, \chi^{2}$ test).

Overall, hMAM expression was found in $74 \%$ of malignancy-associated effusion samples, whereas a

\section{Table 1. hMAM Expression in Controls and Tissues Analyzed by Nested RT-PCR}

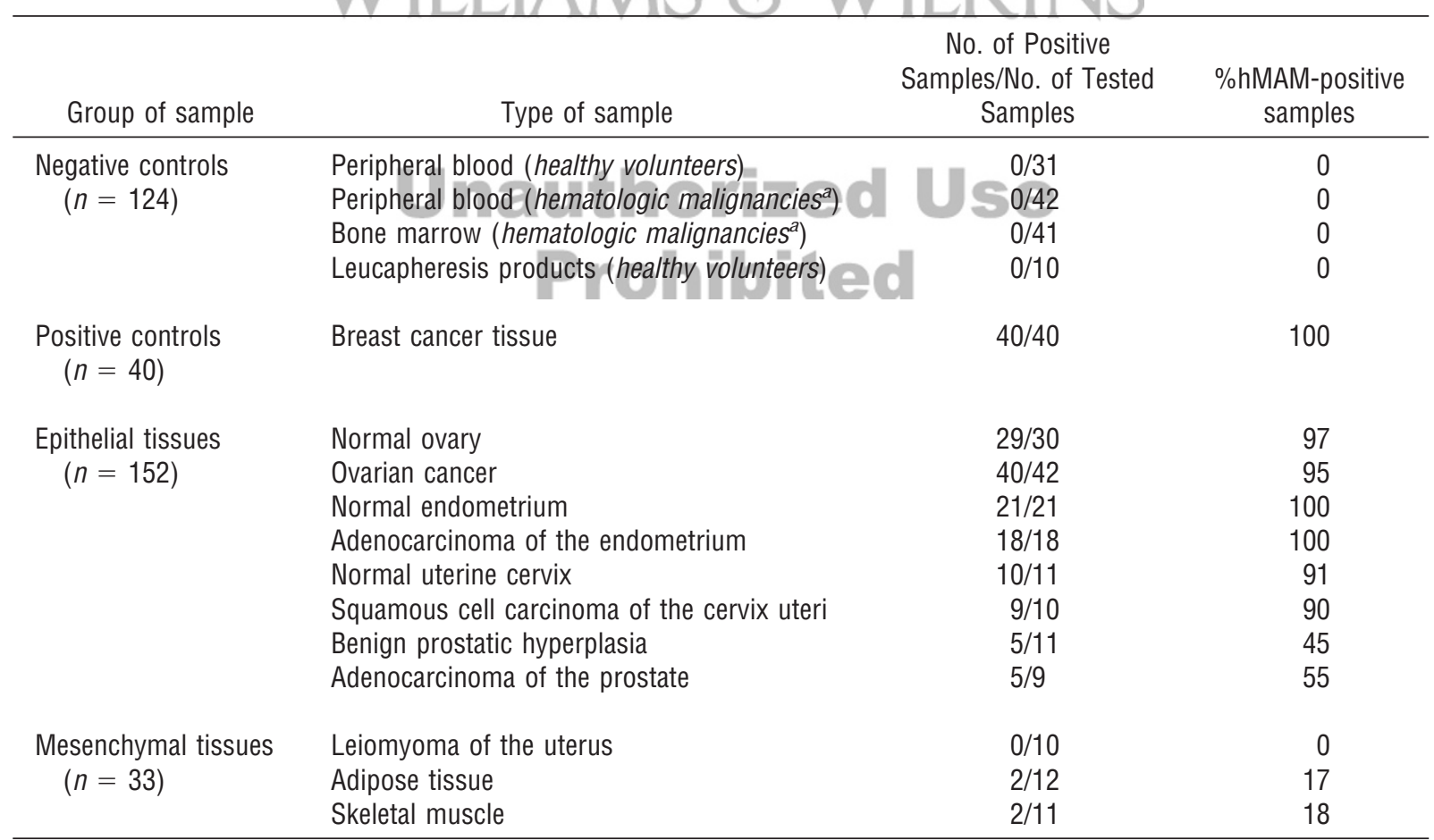

\footnotetext{
a Patients with acute lymphoblastic leukemia $(n=26)$, acute myelogenous leukemia $(n=15)$, chronic myelogenous leukemia $(n=31)$, osteomyelosclerosis $(n=$ $3)$, and essential thrombocythemia $(n=8)$.
} 
Table 2. Cytology and hMAM Expression in Effusions from Patients with Gynecologic Tumors Analyzed by Nested RT-PCR

\begin{tabular}{|c|c|c|c|c|c|c|}
\hline Patients $^{a}$ & Material & Diagnosis & Grading (WHO) & Stage $^{b}$ & hMAM & Cytology \\
\hline ZK & $\mathrm{P}$ & Carcinoma of the breast & ॥ & II & + & $\mathrm{n}$ \\
\hline WW & $P$ & Carcinoma of the breast & $\|$ & II a & + & $n$ \\
\hline SE & A & Carcinoma of the breast & III & II a & + & $\mathrm{n}$ \\
\hline WV & $\mathrm{P}$ & Carcinoma of the breast & III & II a & + & $n$ \\
\hline $\mathrm{KT}^{1}$ & $\mathrm{P}$ & Carcinoma of the breast & III & III a & + & $n$ \\
\hline HS & $\mathrm{P}$ & Carcinoma of the breast & $\|$ & III a & + & $\mathrm{n}$ \\
\hline $\mathrm{SM}^{2}$ & $\mathrm{P}$ & Carcinoma of the breast & III & III b & + & $n$ \\
\hline $\mathrm{KT}^{1}$ & $P$ & Carcinoma of the breast & III & III a & + & $\mathrm{n}$ \\
\hline $\mathrm{SM}^{2}$ & $P$ & Carcinoma of the breast & III & III b & + & $n$ \\
\hline SN & $P$ & Carcinoma of the breast & $\|$ & II a & + & $\mathrm{s}$ \\
\hline$T A^{3}$ & $P$ & Carcinoma of the breast & III & $\| \mathrm{b}$ & + & $\mathrm{p}$ \\
\hline $\mathrm{TA}^{3}$ & $\mathrm{P}$ & Carcinoma of the breast & III & $\| \mathrm{b}$ & + & $\mathrm{p}$ \\
\hline WM & $P$ & Carcinoma of the breast & । & I & + & $p$ \\
\hline LA & $P$ & Carcinoma of the breast & III & IV & + & $p$ \\
\hline HK & $\mathrm{P}$ & Carcinoma of the breast & ॥ & IV & + & $p$ \\
\hline $\mathrm{KT}^{1}$ & $P$ & Carcinoma of the breast & III & III a & + & $p$ \\
\hline IM & L & Carcinoma of the endometrium & $\|$ & $\mathrm{FIGO} \mathrm{Ib}$ & + & $\mathrm{n}$ \\
\hline WE & $\mathrm{P}$ & Carcinoma of the endometrium & । & FIGO III C & + & $\mathrm{s}$ \\
\hline VE & A & Carcinoma of the endometrium & III & FIGO III C & + & $p$ \\
\hline AW & A & Carcinoma of the endometrium & III & FIGO III C & + & $p$ \\
\hline $\mathrm{KM}^{4}$ & $\mathrm{P}$ & Carcinoma of the endometrium & $\|$ & FIGO IV b & + & $p$ \\
\hline $\mathrm{KM}^{4}$ & $\mathrm{P}$ & Carcinoma of the endometrium & $\|$ & FIGO IV b & + & $p$ \\
\hline $\mathrm{KM}^{4}$ & $P$ & Carcinoma of the endometrium & $\|$ & FIGO IV b & + & $\mathrm{p}$ \\
\hline SP & L & Carcinoma of the endometrium & III & FIGO I a & - & $\mathrm{n}$ \\
\hline SA & $\bar{L}$ & Carcinoma of the endometrium & III & FIGO IV b & - & $n$ \\
\hline $\mathrm{JM}^{5}$ & A & Carcinoma of the ovary & III & FIGO IIIC & + & $\mathrm{p}$ \\
\hline$M G$ & $A$ & Carcinoma of the ovary & III & FIGO IV & + & $\mathrm{n}$ \\
\hline SG & A & Carcinoma of the ovary & III & FIGO III C & + & $\mathrm{p}$ \\
\hline SZ & A & Carcinoma of the ovary & III & FIGO III C & + & $p$ \\
\hline KA & $\mathrm{P}$ & Carcinoma of the ovary & n.a. & FIGOIV & + & $\mathrm{p}$ \\
\hline $\mathrm{UI}$ & $\mathrm{P}$ & Carcinoma of the ovary & II & FIGO III C & + & $p$ \\
\hline $\mathrm{BH}$ & A & Carcinoma of the ovary & III & FIGO III b & - & $\mathrm{n}$ \\
\hline MS & A & Carcinoma of the ovary & n.a. & FIGO III C & - & $n$ \\
\hline ER & $\mathrm{P}$ & Carcinoma of the ovary & n.a. & FIGO IV & - & $\mathrm{s}$ \\
\hline KN & $A$ & Carcinoma of the ovary & I & FIGO III & - & $\mathrm{p}$ \\
\hline SR & A & Carcinoma of the ovary & $\|$ & FIGO III b & - & $p$ \\
\hline $\mathrm{JM}^{5}$ & A & Carcinoma of the ovary $=$ & IIII & FIGO IIIC & - & p \\
\hline $\mathrm{FG}$ & A & Carcinoma of the tube & III & FIGO III C & + & $\mathrm{p}$ \\
\hline $\mathrm{BA}^{6}$ & $\mathrm{P}$ & Granulosa cell tumor of the ovary & n.a. & FIGO II & + & $\mathrm{s}$ \\
\hline $\mathrm{BA}^{6}$ & $P$ & Granulosa cell tumor of the ovary & n.a. & FIGO II & - & $n$ \\
\hline PE & A & Malignant germ cell tumor of the ovary & n.a. & n.a. & - & $\mathrm{p}$ \\
\hline SE & A & Squamous cell carcinoma of the cervix uteri & I & FIGO IV a & - & $\mathrm{p}$ \\
\hline
\end{tabular}

P, pleural effusion; A, ascitic effusion; L, lavage fluid; n, normal; s, suspect; p, positive for malignant cells; n.a., not available; WHO, World Health Organization. a Patient in whom repeated effusions were analysed are indicated by footnote numbers.

${ }^{b}$ Stage at initial diagnosis.

positive tumor cell cytology was obtained in only $52 \%$ of these specimens. This points to superior sensitivity of hMAM testing in comparison to cytologic examination for the detection of tumor cells in effusions ( $p=0.08$, McNemar test). In fact, cytology of the invariably hMAM-positive effusions $(n=16)$ from breast cancer patients revealed malignant cells in only $38 \%$. In hMAM-positive effusion samples and lavages from patients with endometrial or ovarian carcinoma, tumor cell cytology was positive in $71 \%$ and $83 \%$, respectively (Table 2). Thus, in this study a considerable proportion of hMAM-positive effusion or lavage samples from various gynecologic tumors were negative by cytology, indicating micrometastatic disease that can be detected by nested RT-PCR. 
Table 3. hMAM Expression in Control Effusions from Patients with Hematologic Disorders and Diseases Other than Cancer Analyzed by Nested RT-PCR

\begin{tabular}{lrcc}
\hline \multicolumn{1}{c}{ Diagnosis } & No. & Material & hMAM positive \\
\hline Coronary heart disease & 19 & $\mathrm{P}$ & $2 / 19$ \\
Liver cirrhosis & 20 & $\mathrm{~A}$ & $2 / 20$ \\
Liver cirrhosis & 1 & $\mathrm{P}$ & $0 / 1$ \\
Pulmonary tuberculosis & 4 & $\mathrm{P}$ & $0 / 4$ \\
Pneumonia & 5 & $\mathrm{P}$ & $1 / 5$ \\
Pulmonary embolism & 3 & $\mathrm{P}$ & $0 / 3$ \\
Hemaotologic disorders $^{a}$ & 3 & $\mathrm{~A}$ & $0 / 3$ \\
Hemaotologic disorders $^{a}$ & 7 & $\mathrm{P}$ & $0 / 7$ \\
Others $^{b}$ & 8 & $\mathrm{P}$ & $0 / 8$ \\
Total $^{\text {atal }}$ & 70 & & $5 / 70$ \\
\hline
\end{tabular}

\footnotetext{
a Idiopathic myelofibrosis $(n=2)$, Hodgkin's disease $(n=3)$, lymphoma $(n=5)$.

${ }^{b}$ Gorham disease $(n=1)$, HIV $(n=1)$, unknown origin $(n=2)$, lung transplantation $(n=4)$.
}

hMAM-positive effusions or lavage fluids without detectable malignant cells from breast, endometrial, and ovarian carcinomas were associated with documented preexisting tumor involvement of peritoneal/ pleural space or with clinically overt disease progression in all but two cases (cases ZK and IM). In these two patients, no other signs of tumor relapse or progression were recorded at the time of effusion sampling.

\section{Discussion}

This study demonstrates hMAM expression in a high proportion of normal and malignant tissues derived from the female genital tract and the prostate and in malignant effusions associated with gynecologic malignancies. A sensitive two-step RT-PCR was used to detect hMAM transcripts. To exclude nonspecific amplification of hMAM-related target cDNAs (ie, members of the uteroglobin family such as mammaglobin B), the amplification products of selected specimens were sequenced. Confirmation of hMAM specificity is particularly relevant for uterus and prostate tissues, in which other members of the uteroglobin family such as Clara cell 10-kDa protein and rat prostatic steroidbinding protein subunit C3 (part of the tetrameric major secretory protein) can be expressed (Parker et al, 1983; Peri et al, 1993).

Until recently, hMAM expression was assumed to be strictly confined to mammary tissues (Watson and Fleming, 1996). Using hMAM as a presumably mammary tissue-specific molecular marker and RT-PCR technology, we and others aimed at detecting micrometastatic breast carcinoma cells in axillary lymph nodes, peripheral blood, bone marrow, and stem cell harvests (Grünewald et al, 2000; Kataoka et al, 2000; Leygue et al, 1999; Manzotti et al, 2001; Marchetti et al, 2001; Min et al, 1998; Ooka et al, 2000, 2001; Zach et al, 1999). However, when screening malignant effusions for micrometastatic disease, we observed hMAM positivity in patients with endometrial and ovarian cancer also. Furthermore, a recent report by Suchy and coworkers points to "ectopic" hMAM expression outside the breast (Suchy et al, 2000). These authors found hMAM expression in various human non-breast cancer cell lines and in peripheral blood samples from a small number of patients with epithelial ovarian cancer. In addition, Fleming and Watson (2000) observed hMAM expression in endometrial carcinoma. Krueger and colleagues reported hMAM expression in various non-breast carcinoma cell lines and in a small percentage of cultured bone marrow and leukapheresis products (Krueger et al, 2001).

To further investigate hMAM expression outside the breast and to estimate its clinical and diagnostic role, we tested a large series of normal and malignant tissues and effusion specimens derived from patients with various gynecologic malignancies for the presence of hMAM mRNA. Normal and neoplastic prostate tissues were included in this analysis because the major secretory protein, another member of the uteroglobin gene family, can be expressed in the ventral prostate tissue of rats (Lea et al, 1979; Parker et al, 1983). Finally, we included a series of mesenchymal specimens to see whether hMAM is expressed in tissues of mesodermal origin.

In addition to breast carcinoma, we also detected hMAM expression in various gynecologic tumors and prostate cancer. In fact, hMAM-specific mRNA was detectable in a high proportion (range, 45-100\%) of normal and malignant epithelial tissues derived from the female genital tract and the prostate, respectively, whereas most samples of nonmalignant mesenchymal tissues were hMAM negative (Table 1). Remarkably, hMAM expression was also detectable in most effusions from patients with gynecologic malignancies (Table 2). In contrast to this, we did not observe hMAM transcripts in either peripheral blood and leukapheresis products from healthy volunteers or in bone marrow aspirates and peripheral blood from patients with hematologic malignancies (Table 1).

Of note, hMAM expression was rarely found in effusions collected from patients with liver cirrhosis or coronary heart disease. Up to this point, it remains a matter of speculation whether low-level hMAM expression in nonmalignant effusions can be caused by ectopic hMAM-producing cells in the peritoneal space (eg, endometriosis) or by cytokine-stimulated inflammatory cells. As reported, in vitro expression of hMAM by blood mononuclear cells is inducible by cytokines, namely granulocyte macrophage-CSF, IL-3, INF- $\gamma$, and thrombopoietin (Krueger et al, 2001). Only careful monitoring of patients with hMAM-positive effusions but without clinical evidence of malignancy can clarify the diagnostic and/or prognostic value of hMAM expression, which could potentially occur as a result of the presence of an occult neoplasm or premalignant lesions in such cases. Notably, in breast cancer patients, hMAM positivity of blood or bone marrow samples after curative surgery correlated with highrisk clinicopathologic parameters and markers for poor prognosis (Grünewald et al, 2000; Ooka et al, 2001; Zach et al, 1999). 
To clarify whether hMAM mRNA levels differ between mammary and other hMAM-expressing tissues on the one hand and between benign and corresponding malignant tissues on the other, hMAM quantification studies by real-time PCR have been started in our laboratory. Preliminary data show significantly higher hMAM expression rates in mammary tissues than in ovarian and endometrial tissues. Furthermore, quantitative PCR shows higher hMAM expression in malignant than in corresponding benign mammary tissues (our unpublished data).

Can hMAM testing of blood and other body fluids by nested RT-PCR impact clinical decision making? Although hMAM expression assayed by nested RT-PCR provides a sensitive marker for detecting micrometastatic or minimal residual epithelial cancer cells originating from the mammary gland, the ovary, and the uterus, published data on hMAM expression from various research laboratories require validation in larger patient populations in a prospective fashion. With this aim in view, we have recently launched a major prospective study to investigate the prognostic value of hMAM expression in blood, lymph nodes, and effusions from patients with nonmetastatic, gynecologic tumors. Because the limitations and pitfalls of cytologic examinations of effusions are well known (Fiegl et al, 2000; Koss, 1992; Sears and Hajdu, 1987), testing of effusions, other body fluids (eg, liquor), or lavages for hMAM expression might well become a method for complementing conventional cytology or immunocytology.

\section{Materials and Methods}

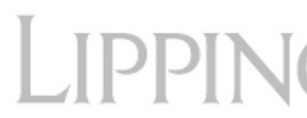

\section{Patients and Healthy Controls}

Tissue Samples. A total of 152 fresh or fresh-frozen (endometrium, uterine cervix, ovary, adipose tissue, skeletal muscle) and formalin-fixed, paraffinembedded tissue samples (prostate, leiomyoma of the uterus) were analyzed in this study (detailed in Table 1). Only tumors with a diameter greater than $1 \mathrm{~cm}$ were analyzed. The percentage of tumor cells was between $70 \%$ and $95 \%$ as documented by histopathologic evaluation. Normal, nonmalignant tissues were collected from patients without cancer, with rare exceptions. In these few cases, benign tissues were sufficiently distanced from tumor tissues as histopathologically verified. The histopathologic characteristics for the malignant tissues are given in Table 4. Specimens of nonmalignant prostate tissue were obtained from patients with benign prostatic hyperplasia. Controls: Blood samples, bone marrow, and leukapheresis products were collected from 83 patients with hematologic malignancies and from 41 healthy volunteers (Table 1). In addition, 40 tissue samples from primary breast carcinomas were included as a positive control (Table 1).

Effusions. Cells from 42 consecutive effusions derived from 34 patients with gynecologic malignancies (endometrial, cervical, ovarian, and breast cancer) were examined (Table 2). Controls: 23 ascitic and 47 pleural effusions originating from 61 patients with hematologic disorders and diseases other than cancer served as controls (Table 3 ).

\section{Cell Line}

The breast cancer cell line MD-MBA-361 (Cailleau et al, 1978) was used as positive control for the expression of hMAM and also for sensitivity testing of the RT-PCR assay.

\section{RNA Extraction and CDNA}

Total cellular RNA was extracted from the fresh or fresh-frozen tumor tissues, mononuclear cells from peripheral blood, bone marrow and leukapheresis products, and pelleted effusion cells by using RNAclean (AGS GmbH, Heidelberg, Germany) according to the manufacturer's instructions. RNA from formalinfixed, paraffin-embedded tissues was extracted as described (von Weizsacker et al, 1991). In brief, the paraffin was extracted with xylene, followed by two washing steps with $100 \%$ ethanol. The material was then incubated for 6 hours at $60^{\circ} \mathrm{C}$ in a lysis buffer containing $20 \mathrm{~mm}$ Tris- $\mathrm{HCl}(\mathrm{pH} 8.0), 20 \mathrm{~mm}$ EDTA (pH $8.0), 2 \%$ SDS, and $500 \mu \mathrm{g} / \mathrm{ml}$ proteinase $\mathrm{K}$. RNA was purified by phenol extraction and precipitated with 0.6 volume isopropanol in the presence of $0.3 \mathrm{~m} \mathrm{NaAc}(\mathrm{pH}$ 5.3). After precipitation and a washing step, the samples were centrifuged, the supernatant was removed, and the pellets were air dried.

Table 4. Histopathologic Characteristics of the Malignant Tissues

\begin{tabular}{|c|c|c|c|c|c|c|c|c|c|}
\hline \multirow[b]{2}{*}{ Histologic type } & \multicolumn{3}{|c|}{ Grading (WHO) } & \multicolumn{3}{|c|}{ FIGO stage } & \multicolumn{3}{|c|}{$\begin{array}{l}\text { GLEASON } \\
\text { Score }\end{array}$} \\
\hline & I & II & III & I & $\|$ & III & 6 & 7 & 9 \\
\hline \multicolumn{10}{|l|}{ Uterus } \\
\hline Adenocarcinoma of the endometrium $(n=18)$ & 4 & 11 & 3 & 13 & 2 & 3 & & - & \\
\hline Squamous cell carcinoma of the cervix uteri $(n=10)$ & 0 & 8 & 2 & 8 & 2 & 0 & & & \\
\hline \multicolumn{10}{|l|}{ Ovary } \\
\hline Serous adenocarcinoma $(n=17)$ & 2 & 11 & 4 & 4 & 2 & 11 & & - & \\
\hline Mucinous adenocarcinoma $(n=25)$ & 3 & 18 & 4 & 16 & 2 & 7 & & & \\
\hline \multicolumn{10}{|l|}{ Prostate } \\
\hline Adenocarcinoma $(n=9)$ & 0 & 8 & 1 & & & & 5 & 3 & 1 \\
\hline
\end{tabular}


Table 5. Primer Sequences for RT-PCR, Including Length of Expected PCR Product and the Specific Annealing Temperature for each Primer Pair

\begin{tabular}{|c|c|c|c|}
\hline Primer & Length (bp) & Sequence $\left(5^{\prime}-3^{\prime}\right)$ & Tm \\
\hline \multicolumn{4}{|l|}{ Fresh, fresh-frozen samples } \\
\hline GAPDH & 598 & $\begin{array}{l}\text { CCA CCC ATG GCA AAT TCC ATG GCA } \\
\text { TCT AGA CGG CAG GTC AGG TCC ACC }\end{array}$ & $60^{\circ} \mathrm{C}$ \\
\hline hMAM outer & 402 & $\begin{array}{l}\text { CAG CGG CTT CCT TGA TCC TTG } \\
\text { ATA AGA AAG AGA AGG TGT GG }\end{array}$ & $57^{\circ} \mathrm{C}$ \\
\hline hMAM inner & 367 & $\begin{array}{l}\text { TGA ACA CCG ACA GCA GCA G } \\
\text { TCC GTA GTT GGT TTC TCA CC }\end{array}$ & $60^{\circ} \mathrm{C}$ \\
\hline \multicolumn{4}{|c|}{ Paraffin-embedded tissues and effusion cells } \\
\hline GAPDH & 147 & $\begin{array}{l}\text { CCA CCC ATG GCA AAT TCC ATG GCA } \\
\text { CAG TGG ACT CCA CGA CGT ACT C }\end{array}$ & $60^{\circ} \mathrm{C}$ \\
\hline hMAM outer & 171 & $\begin{array}{l}\text { TGC CAT AGA TGA ATT GAA GG } \\
\text { TCC GTA GTT GGT TTC TCA CC }\end{array}$ & $57^{\circ} \mathrm{C}$ \\
\hline hMAM inner & 133 & $\begin{array}{l}\text { CGG ATG AAA CTC TGA GCA ATG T } \\
\text { TCC GTA GTT GGT TTC TCA CC }\end{array}$ & $60^{\circ} \mathrm{C}$ \\
\hline
\end{tabular}

Tm, specific annealing temperature; GAPDH, glyceraldehyde-3-phosphate dehydrogenase; hMAM, human mammoglobin.

First-strand cDNA was synthesized by using Moloney murine leukemia virus reverse transcriptase (Life Technologies, Vienna, Austria). One microgram of RNA was added to $200 \mathrm{U}$ of enzyme, $2 \mu \mathrm{l}$ of $10 \times$ reaction buffer $(500 \mathrm{~mm}$ Tris $\mathrm{HCl}, \mathrm{pH} 8.3,750 \mathrm{~mm} \mathrm{KCl}$, $100 \mathrm{~mm}$ dithiothreitol, $30 \mathrm{~mm} \mathrm{MgCl}_{2}$ ), $1 \mathrm{~mm}$ dNTPs (Amersham Pharmacia Biotech, Piscataway, New Jersey), $20 \mathrm{U}$ of RNAsin (Promega Corporation, Madison, Wisconsin), $5 \mu \mathrm{M}$ random hexamers (Roche Diagnostics, Mannheim, Germany), and $1 \mu \mathrm{M}$ antisense primer to a final volume of $20 \mu \mathrm{l}$. The cDNA synthesis was performed at $37^{\circ} \mathrm{C}$ for 60 minutes. After heat inactivation at $95^{\circ} \mathrm{C}$ for 10 minutes, $2 \mu \mathrm{l}$ of cDNA was subjected to PCR analysis.

\section{PCR and Gel Electrophoresis}

Specific cDNA sequences were amplified in a reaction mix composed of $2 \mu \mathrm{l}$ of CDNA, $5 \mu \mathrm{l}$ of $10 \times$ PCR buffer (100 mm Tris $\mathrm{HCl}, \mathrm{pH} 8.3,500 \mathrm{~mm} \mathrm{KCl,} 15 \mathrm{~mm} \mathrm{MgCl}$, $0.1 \%$ gelatin), $50 \mu \mathrm{m}$ dNTPs, $400 \mathrm{~nm}$ of each specific sense and antisense primer, and $1.5 \mathrm{U}$ of AmpliTaq

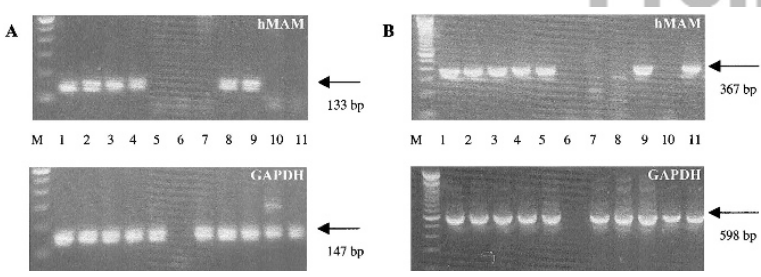

Figure 1.

Nested RT-PCR for human mammaglobin (hMAM) and glyceraldehyde-3phosphate dehydrogenase $(G A P D H)$. A, PCR for effusion cells: 100-bp molecular marker (lane M); effusions from breast cancer (lanes 1 and 2); endometrium cancer (lane 3); ovarian cancer (lane 4); negative control (lane 6); healthy blood donor (lanes 5 and 7); MD-MBA 361 (lanes 8 and 9); and peripheral blood from patients with hematologic disorders (lanes 10 and 11). B, PCR for fresh or fresh-frozen tissues: 100-bp molecular marker (lane M); breast cancer (lane 1); ovarian cancer (lane 2); normal ovary (lane 3); adenocarcinoma of the endometrium (lane 4); normal endometrium (lane 5); negative control (lane 6); healthy blood donor (lanes 7 and 8); MD-MBA 361 (lanes 9 and 11); and leiomyoma of the uterus (lane 10).
DNA polymerase (Perkin Elmer, Vienna, Austria) in a total volume of $50 \mu \mathrm{l}$. The second round of PCR using nested primer and $1 \mu \mathrm{l}$ of outers product was performed identically, except that the dNTP concentration was increased to $100 \mu \mathrm{M}$.

For paraffin-embedded tissues and effusion cells, other primer sets were used because of partial degradation of these RNAs. All primers were synthesized at the MWG-Biotech Laboratory (Ebersberg, Germany). The primer sequences and the specific annealing temperatures are listed in Table 5. The cycling conditions for fresh samples were 40 cycles (30 seconds at $95^{\circ} \mathrm{C}, 60$ seconds at annealing temperature, $60 \mathrm{sec}-$ onds at $72^{\circ} \mathrm{C}$. The cycling conditions for paraffinembedded samples were 40 cycles $(30$ seconds at $95^{\circ} \mathrm{C}, 30$ seconds at annealing temperature, $30 \mathrm{sec}-$ onds at $72^{\circ} \mathrm{C}$ ). As a first step of the PCR, reaction samples were heated to $95^{\circ} \mathrm{C}$ for 3 minutes. At the end of all PCR runs, a last extension was done at $72^{\circ} \mathrm{C}$ for 5 minutes. The RT-PCR products were analyzed in $2 \%$ agarose gels stained with ethidium bromide (Fig. 1). A 100-bp DNA ladder (Life Technologies) was used as a size marker. The presence of intact RNA was confirmed by a single-round RT-PCR using the housekeeping gene glyceraldehyde-3phosphate dehydrogenase.

RNA extracted from the MD-MBA-361 cell line was taken as positive control. Negative controls contained all components of RT-PCR reaction without target RNA template.

To determine the detection limit for hMAM, spiking experiments were performed with peripheral blood mononuclear cells from healthy donors. The MDMBA-361 cell line was chosen as an arbitrary standard for human breast cancer cells. The detection limit for the nested RT-PCR was calculated to be one hMAMexpressing tumor cell among $10^{6}$ mononuclear blood cells. To verify the specificity of the RT-PCR products, Southern blot hybridizations with specific cDNA probes and sequencing analyses were performed. 


\section{References}

Cailleau R, Olive M, and Cruciger QV (1978). Long-term human breast carcinoma cell lines of metastatic origin: Preliminary characterization. In Vitro 14:911-915.

Fiegl M, Kaufmann H, Zojer N, Schuster R, Wiener $\mathrm{H}$, Mullauer L, Roka S, Huber H, and Drach J (2000). Malignant cell detection by fluorescence in situ hybridization (FISH) in effusions from patients with carcinoma. Hum Pathol 31:448455.

Fleming TP and Watson MA (2000). Mammaglobin, a breastspecific gene, and its utility as a marker for breast cancer. Ann NY Acad Sci 923:78-89.

Grünewald K, Haun M, Urbanek M, Fiegl M, Müller-Holzner E, Gunsilius E, Dünser M, Marth C, and Gastl G (2000). Mammaglobin gene expression: A superior marker of breast cancer cells in peripheral blood in comparison to epidermalgrowth-factor receptor and cytokeratin-19. Lab Invest 80: 1071-1077.

Kataoka A, Mori M, Sadanaga N, Ueo H, Tsuji K, Rai Y, Barnard GF, and Sugimachi K (2000). RT-PCR detection of breast cancer cells in sentinel lymph nodes. Int $\mathrm{J}$ Oncol 16:1147-1152.

Koss LG (1992). Diagnostic cytology and its histopathologic bases, 4th ed. Philadelphia, PA: Lippincott.

Krueger WH, Jung R, Detlefsen B, Mumme S, Badbaran A, Brandner J, Renges H, Kroger N, and Zander AR (2001). Interference of cytokeratin-20 and mammaglobin-reversetranscriptase polymerase chain assays designed for the detection of disseminated cancer cells. Med Oncol 18:33-38.

Lea OA, Petrusz P, and French FS (1979) Prostatein: A major secretory protein of the rat ventral prostate. J Biol Chem 254:6196-6202.

Leygue E, Snell L, Dotzlaw H, Hole K, Troup S, HillerHitchcock T, Murphy LC, and Watson PH (1999). Mammaglobin, a potential marker of breast cancer nodal metastasis. J Pathol 189:28-33.

Manzotti M, Dell'Orto P, Maisonneuve P, Zurrida S, Mazzarol $G$, and Viale $G$ (2001). Reverse transcription-polymerase chain reaction assay for multiple mRNA markers in the detection of breast cancer metastases in sentinel lymph nodes. Int J Cancer 95:307-312.

Marchetti A, Buttitta F, Bertacca G, Zavaglia K, Bevilacqua G, Angelucci D, Viacava P, Naccarato A, Bonadio A, Barassi F, Felicioni L, Salvatore S, and Mucilli F (2001). mRNA markers of breast cancer nodal metastases: Comparison between mammaglobin and carcinoembryonic antigen in 248 patients. J Pathol 195:186-190.

Min CJ, Tafra L, and Verbanac KM (1998). Identification of superior markers for polymerase chain reaction detection of breast cancer metastases in sentinel lymph nodes. Cancer Res 58:4581-4584.
Ooka M, Sakita I, Fujiwara Y, Tamaki Y, Yamamoto H, Aihara T, Miyazaki M, Kadota M, Masuda N, Sugita Y, Iwao K, and Monden M (2000). Selection of mRNA markers for detection of lymph node micrometastases in breast cancer patients. Oncol Rep 7:561-566.

Ooka M, Tamaki Y, Sakita I, Fujiwara Y, Yamamoto H, Miyake Y, Sekimoto M, Ohue M, Sugita Y, Miyoshi Y, Ikeda N, Noguchi S, and Monden M (2001). Bone marrow micrometastases detected by RT-PCR for mammaglobin can be an alternative prognostic factor of breast cancer. Breast Cancer Res Treat 67:169-175.

Parker MG, White R, Hurst H, Needham M, and Tilly R (1983). Prostatic steroid-binding protein: Isolation and characterization of C3 genes. J Biol Chem 258:12-15.

Peri A, Cordella-Miele E, Miele L, and Mukherjee AB (1993). Tissue-specific expression of the gene coding for human Clara cell $10-k D$ protein, a phospholipase A2-inhibitory protein. J Clin Invest 92:2099-2109.

Sears D and Hajdu SI (1987). The cytologic diagnosis of malignant neoplasms in pleural and peritoneal effusions. Acta Cytol 31:85-97.

Suchy B, Austrup F, Driesel G, Eder C, Kusiak I, Uciechowski $P$, Grill H, and Giesing M (2000). Detection of mammaglobin expressing cells in blood of breast cancer patients. Cancer Lett 158:171-178.

von Weizsacker F, Labei S, Koch HK, Oehlert W, Gerok W, and Blum HE (1991). A simple and rapid method for the detection of RNA in formalin-fixed, paraffin-embedded tissues by PCR amplification. Biochem Biophys Res Commun 174:176-180.

Watson MA, Darrow C, Zimonjic DB, Popescu NC, and Fleming TP (1998). Structure and transcriptional regulation of the human mammaglobin gene, a breast cancer associated member of the uteroglobin gene family localized to chromosome 11q13. Oncogene 16:817-824.

Watson MA and Fleming T (1996). Mammaglobin, a mammary-specific member of the uteroglobin gene family, is overexpressed in human breast cancer. Cancer Res 56:860865.

Zach O, Kasparu H, Krieger O, Hehenwarter W, Girschikofsky M, and Lutz D (1999). Detection of circulating mammary carcinoma cells in the peripheral blood of breast cancer patients via a nested reverse transcriptase polymerase chain reaction assay for mammaglobin mRNA. J Clin Oncol 17: 2015-2019. 